\title{
PRODUCTIVITY OF HONEYBEES IN OIL PALM INTEGRATED SYSTEM IN NIGER- DELTA OF NIGERIA
}

\author{
F.N. Emuh ${ }^{* 1}$ and A.U.Ofuoku ${ }^{2}$
}

\begin{abstract}
For two consecutive years in Abbi, Delta State of Niger-Delta of Nigeria one, two and three beehives were integrated in oil palm plantation to determine optimum productivity of the oil-palm honey bee farming system. The fresh fruit bunch (economic yield) of the oil palm was statistically similar at 0, 1, 2 and 3 bee hive(s) per hectare. The honey yield were statistically similar for each bee hive/ $\mathrm{kg} / \mathrm{ha}$ while the total honey yield/production was significantly higher in the order of three > two > one bee hive/ha. Result obtained in this study indicates that productivity of oil palm plantation + three Beehives/ha which produced more honey is recommended.
\end{abstract}

Keywords: African honeybee, economic yield. honey-yield, oil palm

\section{INTRODUCTION}

Honey is sucked nectar, saccharine exudation of plants, modified by honeybees and stored in beehive (s). It is rich in albumen, amino acid, ascorbic acid, copper, folic acid, fructose, glucose, iron, maltose, nicotinic acid, nitrogen, sodium, sucrose, vitamins B1, B2, B5, C4, D and $\mathrm{K}$ (Ayansola, 2003). It is used as tonic food, promotes growth, maintains acid - base balance of the body, has antibiotic properties and used for spiritual and mystical purposes (Holy Bible, 2000; Ayansola, 2003; Ayodele and Onyekuru, 2005)

Most honey is sourced from honeybees in the wild. Honeybees and tree crops especially flowering plants has a symbolic relationship. The flowers provide nectar, a carbohydrate food for the bees, which is a raw material for honey production, while the bees in turn pollinate the flowers which enable the plant to reproduce. The demand for honey supersedes its supply in the tropics especially in Nigeria. This makes honey expensive beyond the reach of the poor resource persons. These short-falls are partially augumented with importation and adulteration of the original honey with burnt sugar. This short-fall and sharp practice of adulteration can be circumvented by adopting apiculture/bee keeping in tree crop plantation. Crops such as oil palm, rubber, cocoa and kolanut have been suggested for integrated system Apiculture. Bee keeping creates employment and regular source of income for the farmer.

Regrettably, however, Bee keeping/Apiculture is unexplored in Nigeria especially NigerDelta region of southern Nigeria which has a lot of trees and tree crops. Consequently, this has necessitated this research work with objective as to evaluate the productivity of Honeybee in Oil palm plantations in Niger-Delta region of Nigeria.

\section{MATERIALS AND METHODS}

The study was conducted from 2005 to 2007 in a 20 years old plantain in Abbi. Abbi is located at $05043 \mathrm{~N}$ and 060 15E of the equator, and in Ndokwa West Local Government Area of Delta State, in Niger Delta of Nigeria. It is in the rainforest zone, which is characterized by wet season between April to September/October in the year.

\footnotetext{
${ }^{1}$ Dept. of Agronomy, Delta State Uni., Nigeria. Email: fnemuh@yahoo.com

${ }^{2}$ Dept. of Ag. Eco. and Ext., Delta State Uni., Nigeria. Email: Ofuoku@yahoo.com
} 
The experiment was designed in Randomized complete block design with 3 replicates. Each plot measured $36 \mathrm{~m} \times 48 \mathrm{~m}$ containing 30 palm trees. The treatment were

T1 Palm tree alone

T2 Palm tree +1 Bee hive

T3 Palm tree +2 Bee hives

T4 Palm tree +3 Bee hives

The total plot size was 2.0736 ha with a total of 360 palm trees. A Kenyan top bar bee hive(s) (Paterson, 1988), was constructed and attached to the middle palm in each plot according to the treatments. The hive stand(s) were coated with spent lubricant to protect the colony from insect/ants. Honey collected from Apis mellifera odansonii (African bee) were introduced in the month of February 2006 and in 2007. Honey yield from African bees' colony/colonies was harvested periodically.

The Fresh Fruit Bunch (FFB), the economic yield was harvested from each of the experimental plots, as they were observed ripe in 2006 and 2007 respectively. The honey yields were harvested twice yearly. These economic yields (FFB and honey) were subjected to analysis of variance (SAS, 1996) and treatment means separated using Duncan Multiple Range test (Duncan, 1955).

\section{RESULTS AND DISCUSSIONS}

\section{ECONOMIC YIELD OF OIL PALM}

The FFB of oil palm as influenced by bee keeping in hive(s) is presented in Table 1.

The FFB was not significantly influenced by Bee in beehives $(P>0.05)$ in years of study. This could be adduced to Honeybees not restricted to certain palm for nectar utilization and pollination since pollination in oil palm was mainly by insects especially Elaeidobius weevils (Jacquemard, 1998). The factors for FFB production of oil palm can be soil nutrient, rainfall and sunshine (Jacquemard, 1998) rather than pollination from the honeybees alone. Since the palm plantation was in favorable environment, could have resulted in no

Table 1: Economic yields of oil palm in oil-palm-Bee farming system

\begin{tabular}{l|l}
\hline Treatments & $\mathrm{t} / \mathrm{ha} / \mathrm{yr}$ \\
\hline T1 Oil-palm plantation alone & $29.83 \mathrm{a}$ \\
T2 Oil palm plantation + Bee live & $29.84 \mathrm{a}$ \\
T3 Oil palm plantation + 2 Bee hives & $29.80 \mathrm{a}$ \\
T4 Oil palm plantation + 3 Bee hives & $29.79 \mathrm{a}$ \\
Mean & 29.81 \\
\hline
\end{tabular}

Values with similar alphabets are not significantly different at $5 \%$ level of probabilities using Duncan Multiple Range test. significant difference in FFB of oil palm trees with or without Bee hive(s). The FFB yield of $29.79-29 \mathrm{t} / \mathrm{ha} / \mathrm{yr}$ is higher than $7.5-15 \mathrm{t} / \mathrm{ha} / \mathrm{yr}$ of some states in Africa and higher than average of 23t/ha of Cote d' Ivoire but lower than economic yield in Malaysia (Jacquemard, 1988). Similarly, Redshaw and Siggs (1993) reported a lower yield of $23.0-26.0 \mathrm{t} / \mathrm{ha} / \mathrm{yr}$ with 143 plants per hectare.

\section{HONEY PRODUCTION}

The honey yields in oil palm - Bee integrated farming systems of 2 years are presented in Table 2. The honey production per hive was statistically similar for 1 or 2 or 3 bee hive(s) per hectare per annum. It ranged from 17.60 to $19.05 \mathrm{~kg}$. However, the honey yield was in the order of 1 beehive > 2 beehives > 3 beehives. The Honey yield agrees with Morton (2001) who reported an average yield of $0-110$ pounds $(0-45.75 \mathrm{~kg})$ per colony and also 
reported higher yield of 56 pounds $(25.40 \mathrm{~kg})$ for 2000 and 60 pounds $(27.26 \mathrm{~kg})$ in Southeast of United Kingdom. Similarly, Thimann and Manrique (2002) reported honey yield of 17$26 \mathrm{~kg} /$ hive in colonies in Brazil for each of 2 harvests per annum which is lower than Venezuelans average yield of $20 \mathrm{~kg} /$ colony (Manrique and Piccirillio, 2001).

The total honey yield was observed highest in 3 beehives per hectare per annum and was significantly higher than $(P<0.05)$ the yield of 2 or 1 beehive per hectare per annum (Table 2 ). The higher yield can be adduced from strong colonies having larger number of forager

Table 2: Honey yield s in oil-palm-Bee farming system

\begin{tabular}{lll}
\hline Treatments & $\begin{array}{l}\text { Honey yield }(\mathrm{Kg} \\
\text { /hive annum) }\end{array}$ & $\begin{array}{l}\text { Honey } \\
\text { (Kg/ha/annum) }\end{array}$ \\
\hline T2 1 Bee hive + Oil palm plantation & $19.05 \mathrm{a}$ & $38.10 \mathrm{c}$ \\
T3 2 Bee hives+ Oil palm plantation & $18.10 \mathrm{a}$ & $72.40 \mathrm{~b}$ \\
T4 3 Bee hives+ Oil palm plantation & $17.60 \mathrm{a}$ & $106.00 \mathrm{a}$ \\
Mean & 18.25 & 72.17 \\
\hline
\end{tabular}

Values with similar alphabets are not significantly different at $5 \%$ level of probabilities using Duncan Multiple Range test. bees with available palm plantain and other flowering plants. This congruent Ferrar (1993) who reported that Beekeeper's main interest is to maintain healthy and strong colonies, which results in higher honey yield.

\section{CONCLUSIONS}

This study has therefore shown that 3 bee hives in oil palm plantation significantly out yielded 2 or 1 bee hive(s) per hectare per annum in honey production is thus recommended in oil palm plantation is a steady source of income from apiculture, since it does not depreciate the yield of oil palm.

\section{REFERENCES}

Ayansola, B., 2003. Honeybees: Bioecology, Honey Production and Utilization (first edition).Trankhei and Co., Ibadan, Nigeria.

Ayodele, I. A. and K. E. Onyekuru, 2005. Essentials of Bee Keeping (second edition). College Press and Publisher Ltd., Jericho. Ibadan, Nigeria.

Duncan, D. B., 1955. Multiple Range and Multiple F-test Biometrics. ......, 11:25-40.

Ferrar, C., 1993. Productive management of honeybees. American Bee Journal, 133(1):29-31.

Holy Bible, 2000. Honey: Its Uses Proverbs 24:13 Songs of Solomon. 5:11. Reverse Standard Version. 6th Edition.

Jacquemard, J. C., 1998. The Tropical Agriculturalist: Oil palm (first edition). CTA/Macmillan Publishers.

Manrique, A. and G. Piccirillio, 2001. Impact and Current situation of the Africanized bee in Venezuela. xxxvii International Apicultural Congress, Durban, South Africa.

Morton, J., 2001. South-east honey yield and price survey. South East Regional Bee Inspector, CSL, National bee Unit (in UIC). http://www.csl.gov.uk/prodserv/cons/bees/

Paterson, P. D., 1988. A langstroth hive with top-bar instead of frame, for tropical African bees. Bees World, 69:63-68.

Redshaw, M. J. and A. J. Siggs, 1993. Planting density: agriculture and economic appraisal of various planting strategies. In:Jolani Sukaimi et.al (eds). Agriculture Update and Vision. Proc. Porim Int.palm oil congress, Sept. 20-25, 1993. Kuala Lumpur, Porim, Min. of Primary ind., Malaysia. Pp 223-244.

Southwick, E., 1993. Queen right. American Bee Journal, 133(1):39.

Thimann, R. and A. J. Manrique, 2002. Honey production by two types of Africanized honey bees (hybrids of Aphis Mellifera Scutellata) in Western plains of Venezuela. Zootecnia, 20(2):259-266. 